\title{
CAMBRIDGE
}

\section{Outstanding Titles in Law}

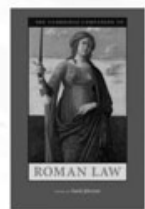

The Cambridge Companion to Roman Law

Edited by David Johnston

S110.00: Hardback: 978-0-521-89564-4: $554 \mathrm{pp}$.

536.99: Paperback 978-0-521-71994-0

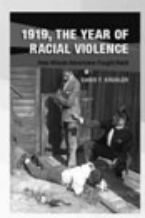

1919, The Year of

Racial Violence

How African Americans Fought Back

David F. Krugler

585.00: Hardback: 978-1-107-06179-8: 344 pp.

529.99: Paperback: $978-1-107-63961-4$

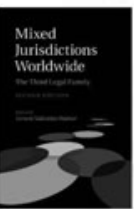

New in Paperback

Mixed Jurisdictions

\section{Worldwide}

The Third Legal Family

Second Edition

Edited by Vernon Valentine Palmer

S49.99: Paperback: 978-1-107-47109-2: 728 pp.

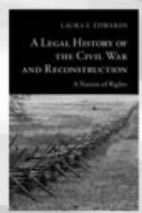

A Legal History of the Civil War and Reconstruction

A Nation of Rights

Laura F. Edwards

New Histories of American Law

s80.00: Hardback: 978-1-107-00879-3:220 pp.

S29.99: Paperback: 978-1-107-40134-1

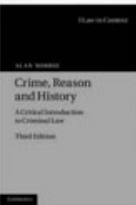

Crime, Reason and History

A Critical Introduction to Criminal

Law

Third Edition

Alan Norrie

Law in Context

S110.00: Hardback:978-0.521-51646-4: 424 pp. \$49.99: Paperback: 978-0-521-73168-3

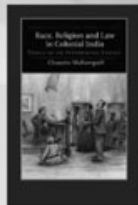

New in Paperback

Race, Religion and Law in Colonial India

Trials of an Interracial Family

Chandra Mallampalli

Cambridge Studies in Indian History and Society

S29.99: Paperback: 978-1-107-48754-3: 288 pf

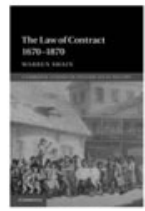

\section{The Law of Contract} 1670-1870

Warren Swain

Cambridge Studies in English Legal History 119.99: Hardback: 978-1-107-04076-2: 368 pp.

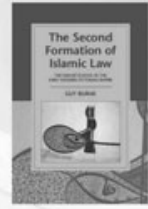

The Second Formation of Islamic Law

The Hanafi School in the Early Modern Ottoman Empire

Guy Burak

Cambridge Studies in Islamic Civilization 599.00: Hardback: 978-1-107-09027-9: 286 pp.

\section{In Defense of Uncle Tom}

Why Blacks Must Police Racial

Loyalty

Brando Simeo Starkey

585.00: Hardback: 978-1-107-07004-2: 376 pp.

529.99: Paperback: 978-1-107-66834-8

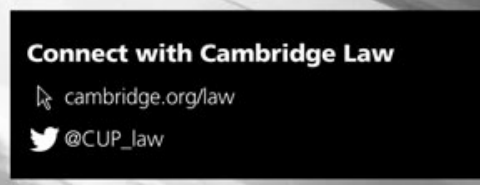




\title{
the SHELBY CULLOM DAVIS CENTER for HISTORICAL STUDIES
}

\author{
http://www.princeton.edu/dav/
}

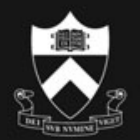

"Risk and Fortune"

Shelby Cullom Davis Center for Historical Studies

During the academic years 2016/17 and 2017/18, the Shelby Cullom Davis Center for Historical Studies will focus on the topic of "Risk and Fortune." Notions of risk have been important to human societies for centuries. Soothsaying, insurance, medical prognostication, financial investment, and gambling all contend with-or try to contain-possible losses. Conversely, good fortune has had its talismans and theorists throughout history. How have different cultures tried to tame chance, or comprehend its whims? To what degree have the practices of commerce relied upon, or alternatively reified, risk? Do technological systems generate hazards they are not capable of controlling? This two-year seminar will bring together scholars working on risk and fortune in historical societies around the world in all time periods, on topics including (but not restricted to) economics, science, religion, industry, statistics, and agriculture.

The Center will offer a limited number of research fellowships for one or two semesters, running from September to January and from February to June. Early career scholars must have their doctoral degrees in hand at the time of the application. Fellows are expected to live in Princeton in order to take an active part in the intellectual interchange with other members of the Seminar. Funds are limited, and candidates are, therefore, strongly urged to apply to other grant-giving institutions as well as the Center if they wish to come for a full year.

To apply please link to: http://jobs.princeton.edu, requisition \#1500396. The deadline for receipt of applications and letters of recommendation for fellowships for $\mathbf{2 0 1 6 / 2 0 1 7}$ is December 1, 2015. Please note that we will not accept faxed applications. Applicants must apply online and submit a CV, cover letter, research proposal, abstract of proposal, and contact information for three references. For further information about the Davis Center, please go to http://www.princeton.edu/dav. Princeton University is an equal opportunity employer. All qualified applicants will receive consideration for employment without regard to race, color, religion, sex, national origin, disability status, protected veteran status, or any other characteristic protected by law. 


\section{American Society for Legal History}

The American Society for Legal History is a nonprofit membership organization dedicated to fostering scholarship, teaching, and study concerning the law and institutions of all legal systems, both AngloAmerican and international. Founded in 1956, the Society sponsors Law and History Review and Studies in Legal History, a series of book-length monographs available to ASLH members at substantial discounts. In addition, the Society holds an annual meeting to promote scholarship and interaction among scholars, practitioners, and students interested in legal history, and maintains a website (http://www.aslh.net) reporting developments in the field. For further information concerning the Society, please write: Sally Hadden, Department of History, Western Michigan University, 4301 Friedmann Hall, Kalamazoo, MI 49008-5334, USA.

To become a member of the Society or to renew your membership please complete, print out, and mail the following form to: Cambridge University Press, Attention: Customer Services, 100 Brook Hill Drive, West Nyack, NY 10994-2133, USA; or print it out and fax it to: 845-353-4141.

\section{Membership Application}

Please check appropriate membership below:

Regular Member, with an annual income

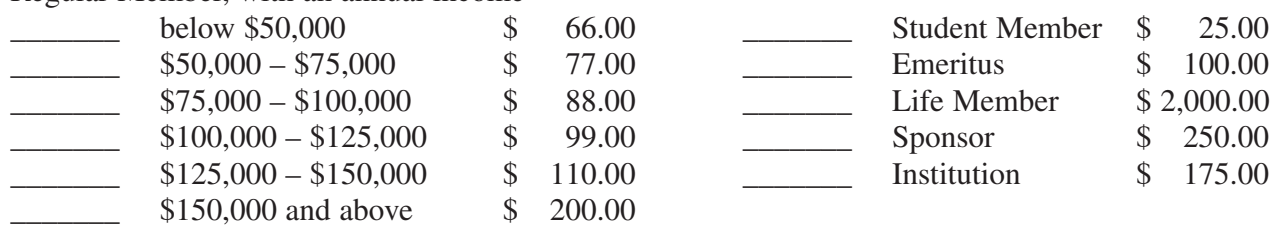

(The Society no longer accepts institutional memberships, but checking this line will make your institution a subscriber to Law and History Review.)

Membership fees must be paid in U.S. dollars by check drawn on a U.S. bank or by MasterCard, Visa, or American Express charge. Questions? Call Cambridge University Press at 1-800-872-7423.

Total Amt: \$ Visa/MC/Amex:

Name on card: Exp. Date:

Signature:

Name:

Institution:

Address:

City: State: Zip:

Country (if not the US):

Phone (Home): (Office):

Fax: E-mail: 


\section{American Society for Legal History}

Michael Grossberg Indiana University President
Officers, 2015

Rebecca Scott

University of Michigan

President-elect

\section{Board of Directors}

Susanna Blumenthal

University of Minnesota

Margot Canaday

Princeton University

Jane Dailey

University of Chicago

Cornelia Dayton

University of Connecticut

Jeremy Kessler

(graduate student

representative), Yale University

Alison LaCroix

University of Chicago

Laura Edwards, Chair

Duke University

Simon Baatz

John Jay College of Criminal

Justice

Holly Brewer

University of Maryland

Li Chen

University of Toronto

Elizabeth Dale

University of Florida

Marie-Amelie George

Yale University
Michael Lobban

Queen Mary College,

University of London

Bruce H. Mann

(Immediate Past President),

Harvard University

Ajay Mehrotra

Indiana University

Patricia H. Minter

Western Kentucky

University

Polly Price

Emory University

\section{Publications Committee}

Sarah Barringer Gordon

University of Pennsylvania

Thomas A. Green

University of Michigan

Martha S. Jones

University of Michigan

Craig Joyce

University of Houston

Craig Evan Klafter

American University of

Myanmar
Craig Klafter

American University of

Myanmar

Treasurer

Sally Hadden

Western Michigan University

Secretary

Reuel Schiller

Univeristy of California,

Hastings

Mitra Sharafi

University of Wisconsin

Karl Shoemaker

University of Wisconsin

David S. Tanenhaus

University of Nevada,

Las Vegas

Karen Tani

University of California,

Berkeley

Michael Lobban

London School of

Economics,

University of London

Jim Phillips

University of Toronto

Rebecca Rix

Princeton University

Charles L. Zelden

Nova Southeastern

University

Honorary Fellows of the American Society for Legal History

Morris S. Arnold

J.H. Baker

John M. Beattie

Mary Frances Berry

Raoul C. Van Caenegem

Ennio Cortese

Charles Donahue

Lawrence M. Friedman

Philip Girard

Paolo Grossi

Douglas Hay
R. H. Helmholz

António Manuel Hespanha

Morton J. Horwitz

Harold M. Hyman

Laura Kalman

Stanley N. Katz

Linda K. Kerber

Bruce Kercher

Peter Landau

Anne Lefebvre-Teillard

Hector L. MacQueen
S. F. C. Milsom

Kjell Modéer

William E. Nelson

John T. Noonan, Jr.

John Phillip Reid

Susan Reynolds

Harry N. Scheiber

Reva Siegel

Peter G. Stein

Michael Stolleis

W. A. J. Watson

\section{Cambridge Journals Online}

For further information about this journal please go to the journal web site at:

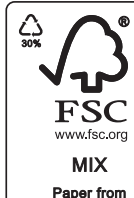

Paper from
CAMBRIDGE UNIVERSITY PRESS 